\title{
An Analysis of Regional Potency and Local Feed Resources to Develop Native Chicken in East Java Province
}

\author{
Didik Nur Edia \\ a Seksi Pembibitan Ternak dan Hijauan Makanan Ternak, UPT Pembibitan Ternak dan Kesehatan Hewan di Madura, Dinas Peternakan \\ Provinsi Jawa Timur \\ email: ${ }^{a}$ didik17101987@gmail.com
}

\begin{tabular}{l}
\hline A R T I C L E I N F O \\
\hline Article history: \\
Received 07 Agustus 2020 \\
Revised 28 Agustus 2020 \\
Accepted 10 Oktober 2020 \\
Available 16 Oktober 2020
\end{tabular}

Keywords:

Native chicken

Location quotient

Local feed

Development

Growth

\begin{abstract}
A B S T R A C T
This study aimed to depict the distribution of potential district/city in East Java Province to develop native chicken based on the analysis of regional potency and local feed resources. The result of this investigation provided basis for preliminary information and a general overview for the direction of native chicken development in East Java Province. The method used in this research were location quotient analysis (LQ), population growth analysis, and local feed potency using secondary data from the BPS-Statistic of East Java Province 20152019. The data were analyzed descriptively. The result showed that there were 12 districts (Trenggalek, Jember, Banyuwangi, Bondowoso, Situbondo, Probolinggo, Sidoarjo, Nganjuk, Ngawi, Bojonegoro, Bangkalan, and Sumenep) and one city (Probolinggo) in East Java Province that potentially developed native chicken. This determination was because those regions acted as the basis of native chicken based on location quotient analysis, positive population growth from 2015-2019, and abundant local feed resources.
\end{abstract}

article:

D. N. Edi, " Analysis of

Regional Potency and Local

Feed Resources for the

Development of Native

Chicken in East Java

Province," Jurnal Ternak

Universitas Islam

Lamongan, vol. 11, no. 2,

pp. 50 - 65, 2020.

Jurnal Ternak (Animal Science Journal) Faculty of Animal Science, Lamongan Islamic University with CC BY NC SA license.

\section{Introduction}

Native chicken is an Indonesian-origin local chicken with a dual function; producing meat and eggs [1]. According to the Directorate General of Livestock and Animal Health [2], meat production of native chickens in East Java Province reached approximately 43,168 tons/year and became the second largest contributor to poultry meat after broiler chickens (277,654 tons/year). In addition, native chickens produced 21,341 tons of eggs/year and became the third-largest contributor of poultry eggs after laying hens (46 5,838 tons/year) and ducks (39,886 tons/year).

Native chickens have several advantages compared to other types of poultry, such as more adaptable to tropical environment under the East Java region, easier to care, and more expensive meat and eggs than commercial chickens. However, it also has shortcomings, such as slow growth rate, small body skeletons, and low egg production [3]. Winarti and Wiranti [4] stated that native chicken meat has a distinctive texture and taste, so that many people like it and had its market segment. Nevertheless, native chicken farming has several obstacles related to the lack of farmers' knowledge, genetics, and government policies. 
One of the supporting factors for the success of business development in a region is depicting the potential areas for determining the adjusted development to regional characteristics. According to Darsono et al. [5], the development of livestock business will be more effective if it is adapted to the technology, social, and economic conditions to support the development of livestock potential, the use of livestock, and the farmers' well-being. Sumanto and Juarini [6] explained that the livestock area potency analysis is a visualization of the evaluation of the livestock development potency to provide the necessary information and a general overview for conceptual and future-oriented planning.

Increasing productivity of native chicken can be made in several ways, including improvement in feed, genetic, and management aspects. Among others, feed is the dominant determining factor in the success of the native chicken business. The feed cost can reach around $70 \%$ of the total production cost of native chicken business [7]. One of the supports for the poultry business's independence is to utilize local feed ingredients [8]. The availability of local feed ingredients will be sustainable because most of the regions in Indonesia have the availability of feed ingredients that unutilized optimally [9]. At present, only $30-40 \%$ of agricultural and plantation waste is used as feed. The waste is in the development area and outside the livestock commodities area so that they need an alternative source of cheap local feed, such as utilizing agricultural waste as feed substitute [10]. In addition, Sadarman et al. [11] stated that it is necessary to explore alternative feed from agro-industrial by-products that are not yet commonly used for livestock development. Furthermore, Dewi [12] explained that the link between agricultural and livestock production areas became essential in developing livestock areas in terms of feed supply.

By looking at the role and potency of native chickens in East Java Province, it was necessary to identify the potency of local feed to support native chickens' productivity and to comprehend the regional potency related to wider development agribusiness, which is adjusted to the character of potential regions. The purpose of this study was to depict the regency/city with potency to develop native chicken in terms of regional analysis and local feed resources. The result of this investigation provided basis for preliminary information and a general overview for the direction native chickens development in East Java Province.

\section{Method}

\subsection{Materials}

The analyzed data were secondary data from the Livestock Service Office and the Central Bureau Statistics of East Java Province 2015-2020 [13-19].

\subsection{Parameters}

\subsubsection{Profile of native chicken in East Java Province}

Profile of native chicken farming was analyzed descriptively, including the development and distribution of native chicken populations.

\subsubsection{Location quotient $(L Q)$ analysis}

LQ analysis was done according to Baharta et al. [20]:

LQi $=\frac{X i / X t}{Y i / Y t}$ 
$\mathrm{Xi}$ : native chicken population in a district/city, $\mathrm{Xt}$ : total poultry population in a district/city, Yi: native chicken population in a province, and Yt: total poultry population in a province. Poultry population included broiler chicken, laying hens, native chicken, ducks, and quails. LQ value $>1$, meaning that the district/city was a basis area of native chicken. The potency of native chicken in this area can be developed for the needs of this area and can fulfil the surrounding area. LQ value $=1$, meaning that the district/city was a non-basis area of native chicken. The potency of native chicken in this area can be developed for the needs of this own area. LQ value $<1$, meaning that the district/city was a nonbasis area of native chicken. This area not potential for the development of native chicken.

\subsubsection{Population growth analysis}

Population growth analysis was carried out in accordance with Suparman [21]. This analysis was used to determine the population growth of native chicken in a certain area. The data used was the population of native chicken from 2015-2019. There were two criteria in this growth analysis, namely positive (+) and negative (-) growth. Growth (+) indicated that the commodity had the potency to be developed, while growth (-) indicated that it had less potential to be developed. The growth analysis formula is:

Population growth $=(\operatorname{Tn}-(\operatorname{Tn}-1)) /(\operatorname{Tn}-1) \times 100 \%$

Tn: native chicken population at the year $\mathrm{n}$ and $\mathrm{Tn}-1$ : native chicken population at the year $\mathrm{n}-1$

\subsubsection{Potency of local feed resources}

The potency of local feed resources can be analysed using the main agricultural product multiplied by the conversion value of by-products or waste and multiplied by their nutrient content [22]. The conversion value of agricultural by-products or waste was based on data from the literature. The potency of local feed resources was calculated using the following formula:

Feed ingredients potency $(\mathrm{kg})$ = agricultural products $(\mathrm{kg}) \times$ conversion value of by-products or waste Crude protein potency $(\mathrm{kg})=$ crude protein content $(\%) \times$ dry matter content $(\%) \times$ potency of feed ingredients $(\mathrm{kg})$.

Metabolizable energy potency $(\mathrm{kcal})=$ metabolizable energy content $(\mathrm{kcal} / \mathrm{kg}) \times$ dry matter content $(\%)$ $\mathrm{x}$ potency of feed ingredients $(\mathrm{kg})$.

\subsubsection{Carrying capacity}

The carrying capacity of native chicken was analyzed with the approach of metabolizable energy and crude protein requirements. According to Sidadolog and Yuwanto [23], the balance of protein-energy and its concentration in the feed can be a biological limitation of feed consumption. Metabolizable energy and crude protein requirements of native chicken according to SNI No. 7783.3:2013 were $2500 \mathrm{kcal} / \mathrm{kg}$ and $16 \%$, respectively. Feed consumption of native chicken was assumed to be 100 grams/day, so the requirements of metabolizable energy and crude protein within a year were as follow:

$\begin{aligned} \text { Metabolizable energy requirement }(\mathrm{kcal} / \text { year }) & =2,500 \mathrm{kcal} / \mathrm{kg} \times 0.1 \mathrm{~kg} / \mathrm{bird} / \text { day } \times 365 \text { days } \\ & =91,250 \mathrm{kcal} / \mathrm{bird} / \mathrm{year} \\ \text { Crude protein requirement }(\mathrm{kg} / \text { year }) & =16 \% \times 0.1 \mathrm{~kg} / \mathrm{bird} / \text { day } \times 365 \text { days } \\ & =5.84 \mathrm{~kg} / \mathrm{bird} / \text { year }\end{aligned}$

Carrying capacity was calculated with the following formula:

Carrying capacity based on metabolizable energy requirement 
$=\frac{\text { Metabolizable energy potency } \times 75 \%}{91,250}$

Carrying capacity based on crude protein requirement $=\frac{\text { Crude protein potency } \times 75 \%}{5.84}$

The $75 \%$ value was based on the total population of native chicken in East Java Province was $75 \%$ of local poultry (native chickens, ducks, Muscovy ducks, quails, and pigeons)[13]. Therefore, it was assumed that $25 \%$ of metabolizable energy and crude protein potency for other local poultries.

\subsubsection{Development potency}

Development potency was assessed by considering the following criteria:

1. LQ value

(basis)

2. Growth value (positive)

3. Carrying capacity based on metabolizable energy requirement (positive)

4. Carrying capacity based on crude protein requirement (positive)

Development potency was calculated by combining criteria 3 and 4 with a ratio of 15625:1 (ratio of metabolizable energy and crude protein requirements).

\subsection{Data analysis}

The method used was descriptive-analytic. This method was done by collecting secondary data from related agencies and then analyzed into explainable information

\section{Result and Discussion}

\subsection{Profile of native chickens farming in East Java Province}

One of the Indonesian superior local poultry commodities is native chickens. The native chickens farming can support the preservation of genetic resources of Indonesian-origin animals. According to Nataamijaya [1], native chickens were highly valuable assets to form superior local chicken breeds and have been proven to adapt to the local environment. Winarti and Wiranti [4] explained that native chickens could grow well at a lower energy and protein level than commercial chickens so that native chickens can grow optimally with local feed ingredients that relatively had low quality. The development of native chickens and the distribution of their population in each district/city in East Java Province is shown in Figures 1 and 2.

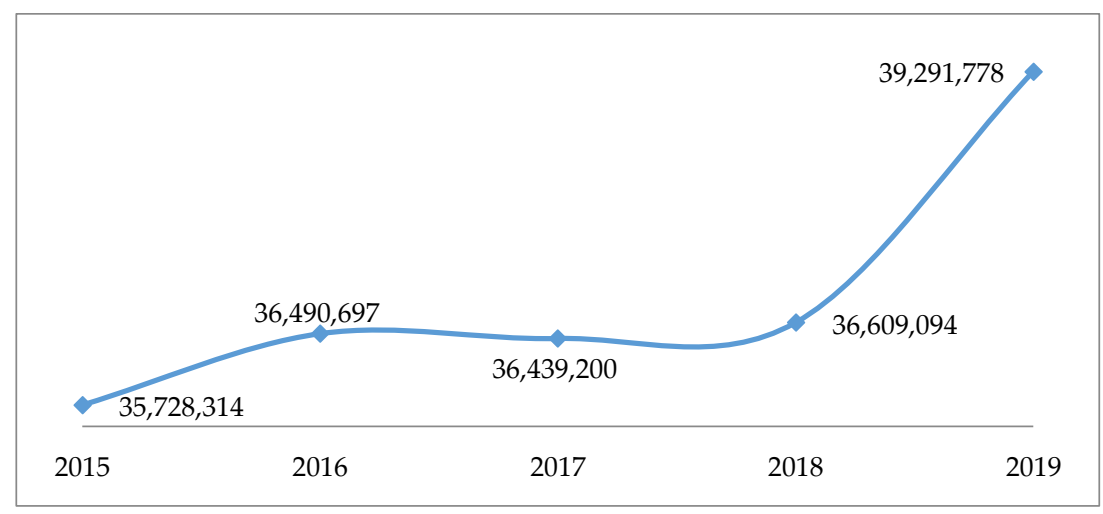


Figure 1. The development of the native chickens' population in East Java Province Source: Livestock Service Office of East Java Province [13]

Figure 1 showed that there was an increasing trend in the native chicken population in East Java Province. The native chicken population increased by $9.97 \%$ from $2015-2019$, with an average increase of $1.99 \%$ each year. The highest increase occurred in 2018-2019, with 2,682,684 birds (7.33\%). This result indicated that the native chickens had the potency to be developed in East Java Province. The livestock population is a general indicator that can be used as a parameter for livestock development [24].

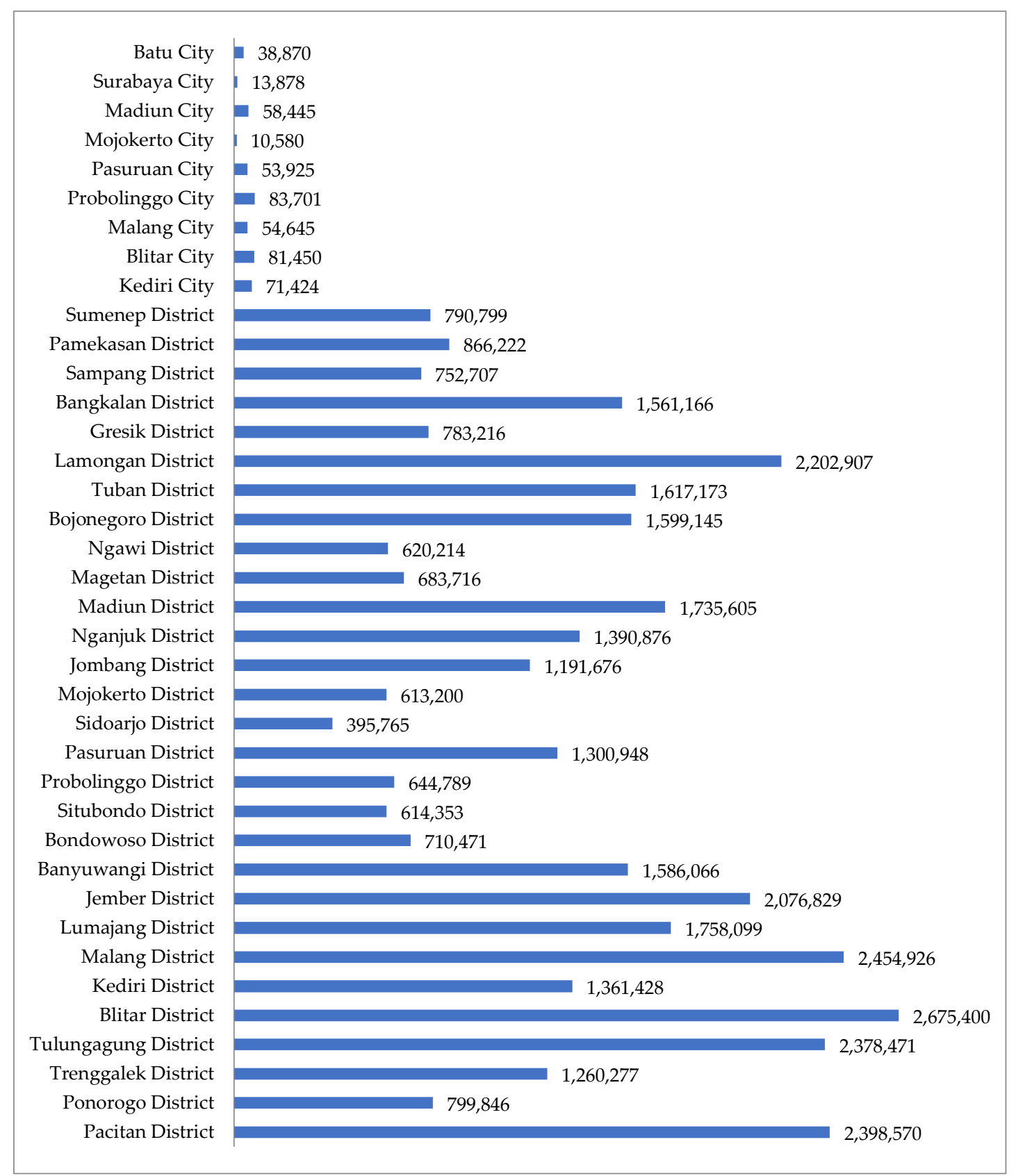

Figure 2. Distribution of the native chicken population in East Java Province Source: BPS-Statistics of East Java Province [19]

As shown in Figure 2, the distribution of native chicken populations in each district/city varied widely. This result illustrated that the development of native chickens was influenced by the characteristics of each district/city. These characteristics can be in the form of feed resources potency, socio-economy, climate, and local government policies. The total population can describe the 
suitability of livestock commodities with the agroecological environment, population dynamics, community acceptance, and the success of reproductive management [24]. Matitaputty and Kuntoro [25] explained that the development of livestock areas must be adapted to the agroecosystem, spatial allocation of areas, and the use of superior or strategic types of livestock.

\subsection{LQ analysis}

LQ analysis is a method to map the potential base of native chickens in an area. This analysis can provide an overview of the potential areas for native chicken development from a perspective of the total population in an area relative to other areas. The result of the LQ analysis of native chickens in East Java Province is shown in Figure 3.

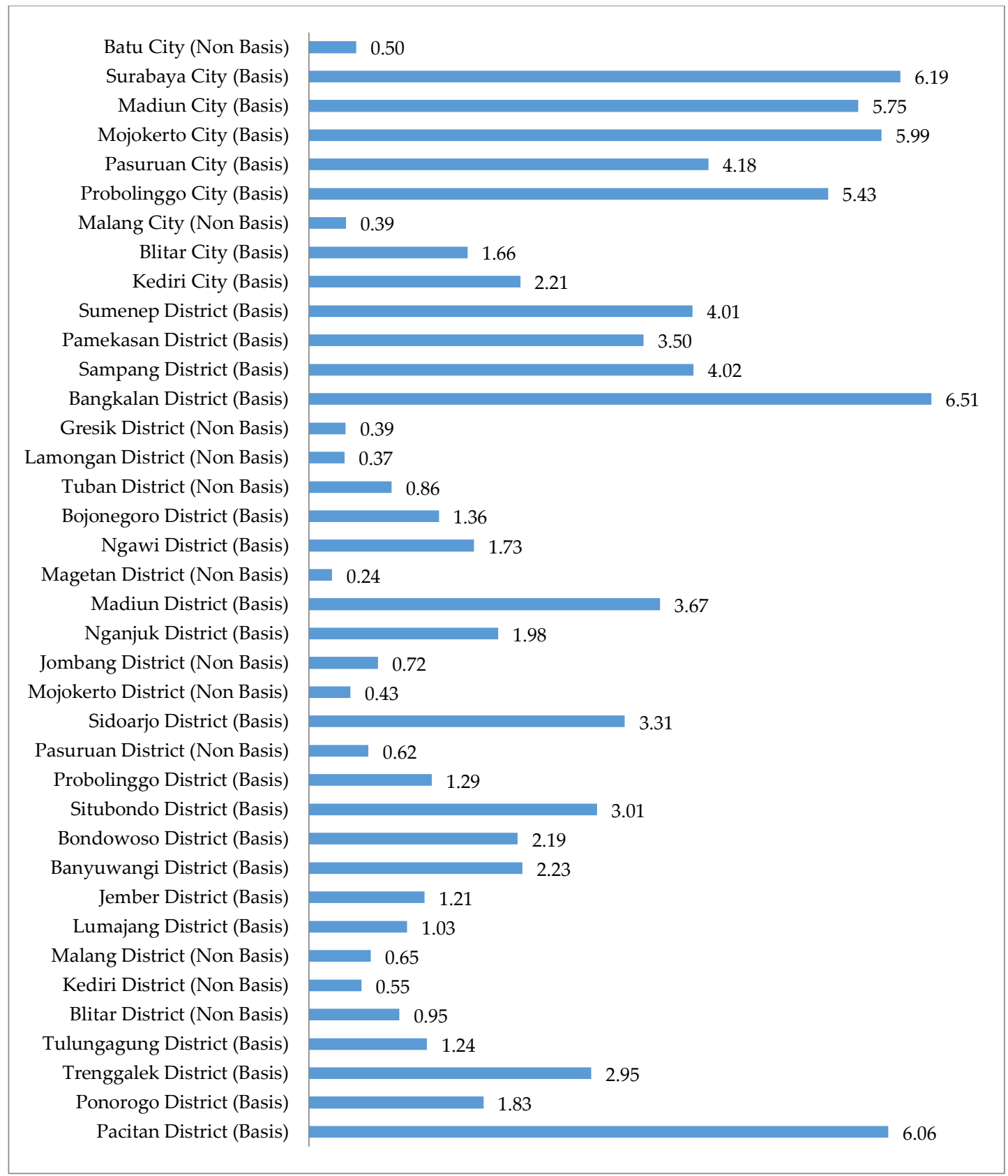

Figure 3. LQ analysis of native chickens in East Java Province Source: Calculation results based on data from the BPS-Statistics of East Java Province [19] 
Table 1. Population growth analysis of native chickens in East Java Province 2015-2019

\begin{tabular}{|c|c|c|c|c|c|}
\hline \multirow{2}{*}{ Area } & \multicolumn{5}{|c|}{ Population growth } \\
\hline & $2015 / 2016$ & $2016 / 2017$ & $2017 / 2018$ & 2018/2019 & Average \\
\hline Pacitan District & 1.00 & 17.14 & 59.30 & 42.74 & 30.05 \\
\hline Ponorogo District & -1.65 & -19.52 & 17.33 & 0.07 & -0.94 \\
\hline Trenggalek District & 4.79 & 3.58 & 4.87 & 21.87 & 8.78 \\
\hline Tulungagung District & -17.93 & 16.37 & -33.71 & -3.31 & -9.65 \\
\hline Blitar District & 5.00 & -4.05 & 0.18 & 2.10 & 0.81 \\
\hline Kediri District & 1.10 & 1.66 & 1.04 & 1.03 & 1.21 \\
\hline Malang District & 2.80 & 2.14 & 2.07 & 1.58 & 2.15 \\
\hline Lumajang District & 1.10 & 29.76 & 30.65 & 0.18 & 15.42 \\
\hline Jember District & 1.50 & 1.71 & 37.93 & -14.13 & 6.75 \\
\hline Banyuwangi District & 25.52 & -23.87 & -2.01 & 47.00 & 11.66 \\
\hline Bondowoso District & 13.51 & 5.67 & 4.76 & 2.34 & 6.57 \\
\hline Situbondo District & 89.11 & -57.76 & -12.21 & 66.42 & 21.39 \\
\hline Probolinggo District & 13.11 & 1.28 & -14.89 & 17.08 & 4.14 \\
\hline Pasuruan District & 0.36 & 0.64 & -0.09 & 1.92 & 0.71 \\
\hline Sidoarjo District & 6.84 & 4.26 & 2.28 & 0.97 & 3.59 \\
\hline Mojokerto District & 0.71 & -6.31 & -4.84 & -8.40 & -4.71 \\
\hline Jombang District & -1.95 & -7.00 & -38.80 & 24.88 & -5.72 \\
\hline Nganjuk District & 0.00 & 0.01 & 0.12 & 13.39 & 3.38 \\
\hline Madiun District & 3.45 & 3.58 & 3.07 & 3.00 & 3.27 \\
\hline Magetan District & -19.09 & -0.02 & 0.68 & 15.31 & -0.78 \\
\hline Ngawi District & 7.23 & -5.92 & 0.99 & 5.02 & 1.83 \\
\hline Bojonegoro District & 0.83 & 1.04 & 1.20 & 1.29 & 1.09 \\
\hline Tuban District & 15.99 & 0.04 & 4.04 & 2.04 & 5.53 \\
\hline Lamongan District & 2.17 & 1.90 & 3.27 & 2.99 & 2.58 \\
\hline Gresik District & 3.30 & 1.27 & 2.01 & 7.79 & 3.59 \\
\hline Bangkalan District & 1.97 & 6.14 & 2.42 & 42.18 & 13.18 \\
\hline Sampang District & 0.12 & 1.66 & -1.57 & -1.28 & -0.27 \\
\hline Pamekasan District & 1.60 & 3.12 & 0.05 & 0.04 & 1.20 \\
\hline Sumenep District & 0.36 & 0.19 & 0.88 & 0.37 & 0.45 \\
\hline Kediri City & -15.80 & -48.43 & 7.01 & 14.81 & -10.60 \\
\hline Blitar City & 4.78 & 3.93 & 28.95 & 0.97 & 9.66 \\
\hline Malang City & 0.24 & 0.29 & 0.11 & 0.15 & 0.20 \\
\hline Probolinggo City & 2.02 & 2.02 & 2.11 & 2.02 & 2.04 \\
\hline Pasuruan City & -0.92 & 0.46 & 10.43 & 11.74 & 5.43 \\
\hline Mojokerto City & -1.92 & 5.88 & -11.85 & -11.09 & -4.75 \\
\hline Madiun City & 3.09 & -6.88 & -4.00 & -4.00 & -2.95 \\
\hline Surabaya City & 5.77 & -19.74 & -38.44 & -0.81 & -13.30 \\
\hline Batu City & -3.27 & -7.77 & -12.94 & 0.25 & -5.93 \\
\hline East Java Province & 2.13 & -0.14 & 0.47 & 7.33 & 2.45 \\
\hline
\end{tabular}

Source: Calculation results based on data from the BPS-Statistics of East Java Province [14-18]

Figure 3 showed that the majority (68.4\%) of districts/cities in East Java Province were the basis of native chickens and only 12 districts/cities categorized into non-basis of native chickens. This result illustrated that the native chickens were one of the superior poultry in East Java Province. According to Suparman [21], the LQ index $>1$ indicated that the area was the basis of livestock commodity. Susanto et al. [26] explained that the fundamental aspect for the development of an area 
based on agricultural commodities was to pay attention to the concentration and the degree of distribution of these commodities in the region.

The basis area with the highest LQ index of native chickens was found in Bangkalan District with 6.51, while the lowest one was Lumajang District with 1.03. The high LQ index illustrated that the area had higher potency for native chicken development. According to Baharta et al. [20], the basis area can function for exchange purposes and able to supply livestock in the area. In addition, Suparman [21] explained that the LQ analysis would obtain economic sectors with the potency to be distributed outside the surrounding area.

\subsection{Population growth analysis}

Population growth analysis is carried out to determine the growth rate of native chickens from an economic point of view each year. This analysis can describe the growth of native chickens in the district/city each year. The results of the population growth analysis are shown in Table 1 . The average growth of the native chicken population in East Java Province during 2015-2019 was 2.45\%. The distribution of population growth analysis in districts/cities showed that $27(71.1 \%)$ districts/cities had a positive value. Whereas, 11 districts/cities $(28.9 \%)$ had a negative value. This result indicated that most districts/cities in East Java Province had the potency to develop native chickens. Population growth (+) indicated that the commodity has the potency to be developed, while the negative value (-) indicated that the commodity has less potential to be developed [21].

Table 1 also showed that 19 districts/cities in East Java Province had a positive value of population growth from 2015 to 2019. This finding indicated that during those periods, the native chickens' population has always increased, and those areas were very potential for the development of native chickens.

\subsection{Potency of local feed resources}

The local feed is a feed ingredient from local resources with potency to be efficiently used as a supplement, part of concentrate, or main feed. The local feed can be in the form of crop residues, byproducts crop, and by-product agroindustry [27]. Sinurat [28] explained that local feed ingredients that can be used to make native chickens' feed included rice bran, cassava and its by-products, coconut meal, tofu waste, palm oil waste, shrimp heads, and snails.

The use of agricultural by-products has several advantages, including high crude protein content at relatively low prices and some agricultural waste that can be used as feed additives. According to Kasapidou et al. [29], fruit and vegetable waste can improve the characteristics and palatability of the main feed because they contain antioxidants and coloring agents. The mannan content in palm kernel meal can be used as an antimicrobial agent against Salmonella typhimurium in chickens by reducing the incidence of Salmonella typhimurium and reducing the number of Salmonella typhimurium colonies in the cecum [30]. Nonetheless, the use of agricultural by-products for poultry feed also has several limitations, such as high antinutrient content, high crude fiber content [31], various nutrient content, seasonal dependent production, bulkiness properties, treatment requirements before usage, limited information on nutrient content, limited use by the cost per unit of amino acids, and more expensive energy than conventional feed ingredients. The processing and limitation of agricultural by-products for poultry feed can be seen in Table 2.

The local feed ingredients studied in this investigation were corn, agricultural by-products, and fruits recorded by BPS-Statistics of East Java Province. Corn has a multipurpose function, namely for food, feed, fuel, and fiber, and it was estimated that around $58 \%$ of domestic needs of corn were used for animal feed [32]. So that, in this study, corn was considered to have a conversion value of $58 \%$. The data of local feed ingredients from agricultural by-products, estimated waste produced as local feed ingredients, and nutrient content for native chicken feed are shown in Table 3. 
Table 2. The processing and limitation of agricultural by-products for poultry feed

\begin{tabular}{|c|c|c|c|c|}
\hline Feed ingredients & Treatment & Poultry type & Limit of use (\%) & References \\
\hline Corn & Without treatment & All & 70 & Bidura [33] \\
\hline Rice bran & Without treatment & Laying hens & 50 & Sinurat [28] \\
\hline Rice polishing & Without treatment & Laying hens & 50 & Sinurat $[28]$ \\
\hline Soybean hull & Fermentation $\left(\mathrm{EM}_{4}\right)$ & Broiler chickens & 7.5 & $\begin{array}{l}\text { Auza and Badaruddin } \\
\text { [34] }\end{array}$ \\
\hline \multirow[t]{2}{*}{ Soybean meal } & Without treatment & Broiler chickens & 32.5 & Astuti [35] \\
\hline & & Laying hens & 20 & Syahruddin et al. [36] \\
\hline Peanut meal & Without treatment & Native chicken & 15 & Bidura [33] \\
\hline Sweet potato peel & Heating at $100-120{ }^{\circ} \mathrm{C}$ for 30 minutes & Broiler chickens & 30 & Widodo [37] \\
\hline Cassava peel & Heating at $100-120{ }^{\circ} \mathrm{C}$ for 30 minutes & All & 15 & Widodo [37] \\
\hline Tapioca waste & Fermentation (Aspergillus niger) & Native chicken & 20 & Widodo [37] \\
\hline Palm kernel meal & Without treatment & Broiler chickens & 40 & Astuti [35] \\
\hline Palm oil sludge & Without treatment & Laying hens & 20 & Sinurat [38] \\
\hline Coconut meal & Without treatment & $\begin{array}{l}\text { Broiler chickens, } \\
\text { laying hens }\end{array}$ & 40 & Sinurat $[28]$ \\
\hline Coffee hull & Without treatment & Broiler chickens & 14 & Tatilu et al. [39] \\
\hline Kapok meal & $\begin{array}{l}\text { Fermentation (Trichoderma } \\
\text { harzianum) }\end{array}$ & Laying hen & 29.3 & Syahruddin et al. [36] \\
\hline Rubber meal & Fermentation (tapai yeast) & Broiler chickens & 20 & Inara $[40]$ \\
\hline Banana peel & Grinding & Broiler chickens & 75 & Hidayat et al. [41] \\
\hline
\end{tabular}

Table 3. Estimation of conversion value and nutrient contents of local feed ingredients in East Java Province

\begin{tabular}{|c|c|c|c|c|c|c|}
\hline Agricultural product & Local feed & $\mathrm{CV}$ & DM (\%) & CP (\%) & ME (kcal/Kg) & References \\
\hline \multirow[t]{2}{*}{ Corn } & Corn & 58 & 84 & 8.5 & 3300 & Panikkai et al. [32] \\
\hline & & & & & & Pratiwi [42] \\
\hline \multirow[t]{4}{*}{ Rice } & Rice bran & 8.5 & 86 & 11.9 & 2730 & Astawan and Febrinda [43] \\
\hline & & & & & & Hartadi [44] \\
\hline & Rice polishing & 3 & 86 & 12 & 2887 & Astawan dan Febrinda [43] \\
\hline & & & & & & Astuti [35] \\
\hline \multirow[t]{3}{*}{ Soybean } & Soybean hull & 7.3 & 94 & 16.2 & 2898 & Auza and Badaruddin [34] \\
\hline & Soybean meal & 78.7 & 86 & 41.3 & 3421 & Dei [45] \\
\hline & & & & & & Astuti [35] \\
\hline Mung bean & Mung bean hull & 10 & 88.5 & 13.5 & 2841 & Surya [46] \\
\hline \multirow[t]{4}{*}{ Peanut } & Peanut hull & 2.3 & 88.6 & 9 & 2501 & Zhao et al. [47] \\
\hline & & & & & & Lindemann et al. [48] \\
\hline & Peanut meal & 70 & 90 & 45.6 & 2664 & Batal et al. [49] \\
\hline & & & & & & Zhao et al. [47] \\
\hline Sweet potato & Sweet potato peel & 16 & 85 & 6.7 & 1544 & Nuraini et al. [50] \\
\hline & & & & & & Agustono et al. [27] \\
\hline \multirow[t]{2}{*}{ Cassava } & Cassava peel & 16 & 67.9 & 4.0 & 2135 & Mirzah and Muis [51] \\
\hline & Tapioca waste & 11.4 & 85.9 & 2.9 & 2783 & Kiramang [52] \\
\hline \multirow[t]{3}{*}{ Palm oil } & Palm kernel meal & 3 & 90 & 15.4 & 2446 & Yanto and Febrina [53] \\
\hline & & & & & & Putri et al. [54] \\
\hline & Palm oil sludge & 15 & 90 & 15.5 & 1593 & Sinurat [38] \\
\hline Coconut & Coconut meal & 30 & 92.9 & 20 & 3248 & Stein et al. [55] \\
\hline Cocoa & Cocoa hull & 72.8 & 93.4 & 10.9 & 2999 & Guntoro dan Yasa [56] \\
\hline Coffee & Coffee hull & 35 & 90 & 10.4 & 3356 & Nuschati [57] \\
\hline Kapok & Kapok meal & 45 & 88.9 & 50.6 & 3712 & Ma et al. [58] \\
\hline Rubber & Rubber meal & 56 & 94 & 26.7 & 2550 & Inara $[40]$ \\
\hline Banana & Banana peel & 35 & 68.9 & 7.0 & 2795 & $\begin{array}{l}\text { Ajila et al. [59], Dorisandi et al. } \\
\text { [60], Hidayat et al. [41] }\end{array}$ \\
\hline
\end{tabular}

CV: conversion value, DM: dry matter, CP: crude protein, ME: metabolizable energy

Based on Table 3, a simple equation can be made by multiplying the conversion value of agricultural products with their nutritional content. Thus, a simple equation was obtained in order to calculate the potency of metabolizable energy and crude protein from agricultural products in an area as follow: 


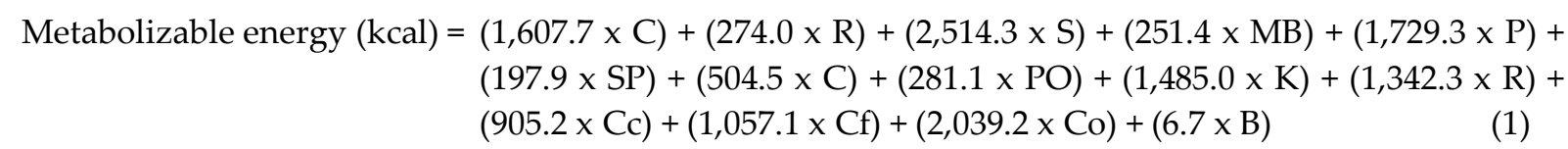

Crude protein $(\mathrm{kg})=(0.041 \times \mathrm{C})+(0.012 \times \mathrm{R})+(0.291 \times \mathrm{S})+(0.012 \times \mathrm{MB})+(0.289 \times \mathrm{P})+(0.009 \times \mathrm{SP})+$ $(0.007 \times \mathrm{C})+(0.025 \times \mathrm{PO})+(0.202 \times \mathrm{K})+(0.141 \times \mathrm{R})+(0.056 \times \mathrm{Cc})+(0.033 \times \mathrm{Cf})+$ $(0.074 \times \mathrm{Co})+(0.017 \times \mathrm{B})$

C: corn, R: rice, S: soybean, MB: mung bean, P: peanut, SP: sweet potato, C: cassava, PO: palm oil, K: kapok, R: rubber, Cc: coconut, Cf: coffee, Co: cocoa, and B: banana.

Table 3 indicated that agricultural sector, not only produced food, but also potentially produced feed for native chickens (around 10-25\%). According to Kasapidou et al. [29], approximately $30 \%$ of agricultural waste can be used for feed and can reduce by-product waste to create the integration of agriculture with livestock farming. Through this integration, the concept of zero waste can be created since the by-product of one component served as a resource for the other components. The use of agro-industrial by-products played a role in overcoming problems in environmental pollution [52].

The potency of metabolizable energy and crude protein from agricultural products in East Java Province can be calculated using Equation (1) and (2) above. The results of the analysis in Table 4 showed that the area that produced the highest metabolizable energy and crude protein was Tuban Districts with 1,073,735 million kcal/year and 39,457 tons/year, respectively, while the lowest one was Mojokerto Districts with 1,221 million kcal/year and 62.1 tons/year, respectively. The high potency of metabolizable energy and crude protein indicated that the area had a high agricultural production to produce high agricultural by-products which can also be used as animal feed ingredients.

\subsection{Carrying capacity and development potency}

The carrying capacity is the ability of an administrative area to accommodate animal feed requirements within a certain period. In poultry, the carrying capacity can be estimated using the requirement of metabolizable energy and crude protein. The balance of energy and protein is a determinant of chickens' performance because instinctively, chickens would stop eating if their metabolizable energy requirements are met [61]. Furthermore, Kiramang [52] stated that chickens will consume feed based on their energy requirements, if the energy requirements are met, the chickens will stop eating and will affect the consumption of protein and other nutrients.

Analysis of the distribution of the carrying capacity of native chickens based on the requirement of metabolizable energy and crude protein from the local feed in East Java Province can be seen in Table 4 . The carrying capacity was based on the requirement of metabolizable energy and crude protein which were assumed to be $91,250 \mathrm{kcal} / \mathrm{bird} /$ year and $5.84 \mathrm{~kg} / \mathrm{bird} /$ year, respectively. The result of the analysis in Table 4 showed that the carrying capacity with the metabolizable energy and crude protein approaches had a different value, which was higher when using the metabolizable energy approach. 
Table 4. Distribution of feed potency and carrying capacity in East Java Province

\begin{tabular}{|c|c|c|c|c|}
\hline \multirow{2}{*}{ Area } & \multicolumn{2}{|c|}{ Feed potency } & \multicolumn{2}{|c|}{ Carrying capacity (birds) } \\
\hline & ME (million kcal/year) & CP (ton/year) & Based on ME & Based on CP \\
\hline Pacitan District & $403,445.0$ & $12,962.9$ & $3,315,986.0$ & $1,664,752.4$ \\
\hline Ponorogo District & $825,446.5$ & $27,082.6$ & $6,784,491.8$ & $3,478,071.4$ \\
\hline Trenggalek District & $347,794.4$ & $12,190.8$ & $2,858,583.8$ & $1,565,602.1$ \\
\hline Tulungagung District & $680,205.8$ & $20,353.1$ & $5,590,732.9$ & $2,613,845.5$ \\
\hline Blitar District & $775,800.5$ & $26,929.3$ & $6,376,442.6$ & $3,458,380.9$ \\
\hline Kediri District & $748,665.0$ & $21,701.4$ & $6,153,411.2$ & $2,786,997.7$ \\
\hline Malang District & $778,652.9$ & $28,658.8$ & $6,399,886.8$ & $3,680,498.5$ \\
\hline Lumajang District & $338,845.8$ & $12,876.9$ & $2,785,033.8$ & $1,653,714.4$ \\
\hline Jember District & $1,004,502.1$ & $38,175.6$ & $8,256,181.6$ & $4,902,683.0$ \\
\hline Banyuwangi District & $624,477.5$ & $31,854.1$ & $5,132,692.1$ & $4,090,852.4$ \\
\hline Bondowoso District & $345,044.9$ & $10,229.4$ & $2,835,985.8$ & $1,313,709.5$ \\
\hline Situbondo District & $446,707.6$ & $12,557.7$ & $3,671,569.0$ & $1,612,722.1$ \\
\hline Probolinggo District & $418,561.3$ & $12,583.6$ & $3,440,229.9$ & $1,616,046.7$ \\
\hline Pasuruan District & $569,593.5$ & $20,846.4$ & $4,681,590.3$ & $2,677,188.5$ \\
\hline Sidoarjo District & $72,721.5$ & $3,601.1$ & $597,710.8$ & $462,476.1$ \\
\hline Mojokerto District & $330,818.4$ & $11,805.1$ & $2,719,055.5$ & $1,516,062.4$ \\
\hline Jombang District & $481,418.5$ & $16,672.3$ & $3,956,864.0$ & $2,141,139.4$ \\
\hline Nganjuk District & $600,628.0$ & $22,178.0$ & $4,936,668.5$ & $2,848,195.8$ \\
\hline Madiun District & $244,185.4$ & $10,736.1$ & $2,007,003.0$ & $1,378,778.6$ \\
\hline Magetan District & $303,031.9$ & $12,167.8$ & $2,490,673.5$ & $1,562,642.4$ \\
\hline Ngawi District & $627,152.7$ & $25,115.4$ & $5,154,679.9$ & $3,225,432.2$ \\
\hline Bojonegoro District & $694,961.1$ & $32,649.9$ & $5,712,008.9$ & $4,193,051.7$ \\
\hline Tuban District & $1,073,735.6$ & $39,457.3$ & $8,825,223.8$ & $5,067,286.3$ \\
\hline Lamongan District & $814,867.0$ & $33,539.4$ & $6,697,537.2$ & $4,307,282.8$ \\
\hline Gresik District & $296,168.6$ & $10,340.4$ & $2,434,262.3$ & $1,327,963.3$ \\
\hline Bangkalan District & $371,414.1$ & $18,921.3$ & $3,052,719.0$ & $2,429,958.4$ \\
\hline Sampang District & $386,817.8$ & $25,650.8$ & $3,179,324.7$ & $3,294,196.5$ \\
\hline Pamekasan District & $196,026.9$ & $6,404.1$ & $1,611,179.6$ & $822,442.4$ \\
\hline Sumenep District & $771,908.7$ & $24,057.3$ & $6,344,455.1$ & $3,089,556.0$ \\
\hline Kediri City & $12,860.1$ & 443.9 & $105,699.5$ & $57,011.5$ \\
\hline Blitar City & $16,058.7$ & 456.0 & $131,989.1$ & $58,557.8$ \\
\hline Malang City & $6,266.6$ & 217.2 & $51,506.4$ & $27,892.3$ \\
\hline Probolinggo City & $42,466.7$ & $1,127.8$ & $349,041.7$ & $144,842.1$ \\
\hline Pasuruan City & $3,059.1$ & $1,544.4$ & $25,143.1$ & $18,549.1$ \\
\hline Mojokerto City & $1,221.1$ & 62.1 & $10,036.5$ & $7,969.8$ \\
\hline Madiun City & $2,848.8$ & 160.6 & $23,414.5$ & $20,629.8$ \\
\hline Surabaya City & $4,116.2$ & 158.4 & $33,831.9$ & $20,336.1$ \\
\hline Batu City & $4,310.4$ & 155.4 & $35,427.6$ & $19,962.5$ \\
\hline East Java Province & $15,666,806,6$ & $585,224.7$ & $128,768,273.8$ & $75,157,280.7$ \\
\hline
\end{tabular}

Source: calculation results

ME: metabolizable energy, $\mathrm{CP}$ : crude protein 
Table 5. The distribution of development potency of native chickens in East Java Province

\begin{tabular}{|c|c|c|c|c|c|c|}
\hline \multirow{2}{*}{ Area } & \multirow{2}{*}{ LQ } & \multirow{2}{*}{ PGA } & \multicolumn{2}{|c|}{ DP (birds) } & \multirow{2}{*}{ DC } & \multirow{2}{*}{ DP (birds) } \\
\hline & & & ME & $\mathrm{CP}$ & & \\
\hline Pacitan District & Basis & + & 917,416 & $-733,818$ & Non-potential & - \\
\hline Ponorogo District & Basis & - & $5,984,646$ & $2,678,225$ & Non-potential & - \\
\hline Trenggalek District & Basis & + & $1,598,307$ & 305,325 & Potential & 305,325 \\
\hline Tulungagung District & Basis & - & $3,212,262$ & 235,375 & Non-potential & - \\
\hline Blitar District & Non-basis & + & $3,701,043$ & 782,981 & Non-potential & - \\
\hline Kediri District & Non-basis & + & $4,791,983$ & $1,425,570$ & Non-potential & - \\
\hline Malang District & Non-basis & + & $3,944,961$ & $1,225,573$ & Non-potential & - \\
\hline Lumajang District & Basis & + & $1,026,935$ & $-104,385$ & Non-potential & - \\
\hline Jember District & Basis & + & $6,179,353$ & $2,825,854$ & Potential & $2,825,854$ \\
\hline Banyuwangi District & Basis & + & $3,546,626$ & $2,504,786$ & Potential & $2,504,786$ \\
\hline Bondowoso District & Basis & + & $2,125,515$ & 603,239 & Potential & 603,239 \\
\hline Situbondo District & Basis & + & $3,057,216$ & 998,369 & Potential & 998,369 \\
\hline Probolinggo District & Basis & + & $2,795,441$ & 971,258 & Potential & 971,258 \\
\hline Pasuruan District & Non-basis & + & $3,380,642$ & $1,376,241$ & Non-potential & - \\
\hline Sidoarjo District & Basis & + & 201,946 & 66,711 & Potential & 66,711 \\
\hline Mojokerto District & Non-basis & - & $2,105,856$ & 902,862 & Non-potential & - \\
\hline Jombang District & Non-basis & - & $2,765,188$ & 949,463 & Non-potential & - \\
\hline Nganjuk District & Basis & + & $3,545,792$ & $1,457,320$ & Potential & $1,457,320$ \\
\hline Madiun District & Basis & + & 271,398 & $-356,826$ & Non-potential & - \\
\hline Magetan District & Non-basis & - & $1,806,958$ & 878,926 & Non-potential & - \\
\hline Ngawi District & Basis & + & $4,534,466$ & $2,605,218$ & Potential & $2,605,218$ \\
\hline Bojonegoro District & Basis & + & $4,112,864$ & $2,593,907$ & Potential & $2,593,907$ \\
\hline Tuban District & Non-basis & + & $7,208,051$ & $3,450,113$ & Non-potential & - \\
\hline Lamongan District & Non-basis & + & $4,494,630$ & $2,104,376$ & Non-potential & - \\
\hline Gresik District & Non-basis & + & $1,651,046$ & 544,747 & Non-potential & - \\
\hline Bangkalan District & Basis & + & $1,491,553$ & 868,792 & Potential & 868,792 \\
\hline Sampang District & Basis & - & $2,426,618$ & $2,541,490$ & Non-potential & - \\
\hline Pamekasan District & Basis & + & 744,958 & $-43,780$ & Non-potential & - \\
\hline Sumenep District & Basis & + & $5,553,656$ & $2,298,757$ & Potential & $2,298,757$ \\
\hline Kediri City & Basis & - & 34,276 & $-14,412$ & Non-potential & - \\
\hline Blitar City & Basis & + & 50,539 & $-22,892$ & Non-potential & - \\
\hline Malang City & Non-basis & + & $-3,139$ & $-26,753$ & Non-potential & - \\
\hline Probolinggo City & Basis & + & 265,341 & 61,141 & Potential & 61,141 \\
\hline Pasuruan City & Basis & + & $-28,782$ & $-35,376$ & Non-potential & - \\
\hline Mojokerto City & Basis & - & -543 & $-2,610$ & Non-potential & - \\
\hline Madiun City & Basis & - & $-35,030$ & $-37,815$ & Non-potential & - \\
\hline Surabaya City & Basis & - & 19,954 & 6,458 & Non-potential & - \\
\hline Batu City & Non-basis & - & $-3,442$ & $-18,908$ & Non-potential & - \\
\hline
\end{tabular}

Source: Calculation results

LQ: location quotient, PGA: population growth analysis, DP: development potency, ME: metabolizable energy, CP: crude protein, DC: development criteria 
The results of the development potency analysis in Table 5 showed that there were 12 districts and one city with potency for the development of native chickens. Those areas were Trenggalek, Jember, Banyuwangi, Bondowoso, Situbondo, Probolinggo, Sidoarjo, Nganjuk, Ngawi, Bojonegoro, Bangkalan, and Sumenep Districts, as well as Probolinggo City. This determination was based on several criteria; the area being the basis of native chickens based on LQ analysis, population growth has always been positive during 2015-2019, the potency of local feed resources was abundant, which exceeded the requirements for existing native chickens (Table 4). The difference between the requirements and potency of local feed resources in those 13 districts/cities converted into metabolizable energy and crude protein was around 6,368,341 million kcal/year and 245,242 tons/year, respectively. Therefore, the potency for native chicken development was around 18,160,677 birds.

The results of the analysis in Table 5 also showed that the area with the greatest development potency was Jember District with 2,825,854 birds, while the lowest one was Probolinggo City with 61,141 birds. This result probably because by the feed potency in Jember District was very abundant, supported by a huge area for agriculture. Probolinggo City has a small carrying capacity because the agricultural land was minimal. Subsequently, the feed produced from agricultural waste was also limited.

\section{Conclusions}

Based on the analysis of location quotient, population growth, and local feed potency, there are 12 districts and one city in East Java Province that had the potency to develop native chicken. The districts are Trenggalek, Jember, Banyuwangi, Bondowoso, Situbondo, Probolinggo, Sidoarjo, Nganjuk, Ngawi, Bojonegoro, Bangkalan, and Sumenep. The potential city to develop native chicken is Probolinggo. This determination is based on several criteria including the area being the basis of native chicken predicated on location quotient analysis, the population growth of native chicken has always been positive from 2015 to 2019, and the local feed resources are abundant. The difference between the feed demand and the feed potency in those 13 areas when converted into metabolizable energy and crude protein contents is around 6,368,341 million kcal/year and 245,242 tons/year, respectively. Thus, the potency for the development of native chicken is around 18,160,677 birds.

\section{References}

[1] A. G. Nataamijaya, "Pengembangan potensi ayam lokal untuk menunjang peningkatan kesejahteraan petani," Jurnal Litbang Pertanian, vol. 29, no. 4, pp. 131-138, 2010.

[2] Directorate General of Livestock and Animal Health, "Livestock and animal health statistics 2018," Ministry of Agriculture Republic of Indonesia, Jakarta, 2018.

[3] E. Permana, "Respon ayam arab (Gallus turcicus) dan ayam kampung (Gallus gallus domesticus) terhadap ransum berserat kasar tinggi dengan menggunakan daun katuk (Sauropus androgynus)," Skripsi, Departemen Ilmu Nutrisi Dan Teknologi Pakan, Fakultas Peternakan Institut Pertanian Bogor, 2012.

[4] E. Winarti and E. W. Wiranti, "Pengaruh penggantian sebagian pakan komersial ayam broiler dengan bahan pakan lain terhadap pertumbuhan ayam kampung dan pendapatan peternak," Jurnal Pengkajian dan Pengembangan Teknologi Pertanian, vol. 16, no. 3, pp. 223-229, 2013.

[5] W. Darsono, E. I. K. Putri, and Nahrowi, "Prioritas wilayah pengembangan ternak ruminansia di Kabupaten Tasikmalaya," Jurnal Ilmu Produksi dan Teknologi Hasil Peternakan, vol. 4, no, 3, pp. 356363, 2016.

[6] Sumanto and E. Juarini, "Potensi kesesuaian lahan untuk pengembangan ternak ruminansia di Propinsi Nusa Tenggara Timur," Seminar Nasional Teknologi Peternakan dan Veteriner, 2004.

[7] A. N. F. Bhakti, "Penambahan tepung kulit kecambah kacang hijau dalam pakan terhadap bobot badan itik hibrida fase starter," Skripsi, Fakultas Peternakan, Universitas Nusantara PGRI Kediri, 2017. 
[8] C. Hidayat, "Pengembangan produksi ayam lokal berbasis bahan pakan lokal," Wartazoa, vol. 22, no. 2, pp. 85-98, 2012.

[9] A. Sutanto and S. N. W. Mulatmi, "Potensi kelayakan bahan pakan organik untuk ayam kampung di Provinsi Jawa Timur," SENASPRO2 Seminar Nasional dan Gelar Produksi, pp. 608-615, 2017.

[10] Y. Yusriani, "Potensi dan pemanfaatan hasil samping tanaman pangan sebagai pakan ternak ruminansia," Prosiding Seminar Nasional Lahan Suboptimal, 2016.

[11] S. Sadarman, M. Ridla, N. Nahrowi, R. Ridwan, RP Harahap, RA Nurfitriani, and A. Jayanegara, Kualitas fisik silase ampas kecap dengan aditif tanin akasia (Acacia mangium Wild.) dan aditif lainnya," Jurnal Peternakan, vol. 16, no. 2, pp. 66-75, 2019.

[12] R. K. Dewi, "Analisis potensi wilayah pengembangan ternak ruminansia di Kabupaten Lamongan," Jurnal Ternak, vol. 9, no. 2, pp. 5-11, 2018.

[13] Livestock Service Office, "Statistik populasi ternak Provinsi Jawa Timur," http://disnak.jatimprov.go.id/web/data/datastatistik, accessed at 29 June 2020.

[14] BPS-Statistics of East Java Province, "Provinsi Jawa Timur dalam angka 2015," East Java Province, 2015.

[15] BPS-Statistics of East Java Province, "Provinsi Jawa Timur dalam angka 2016," East Java Province, 2016.

[16] BPS-Statistics of East Java Province, "Provinsi Jawa Timur dalam angka 2017," East Java Province, 2017.

[17] BPS-Statistics of East Java Province, "Provinsi Jawa Timur dalam angka 2018," East Java Province, 2018.

[18] BPS-Statistics of East Java Province, "Provinsi Jawa Timur dalam angka 2019," East Java Province, 2015.

[19] BPS-Statistics of East Java Province, "Provinsi Jawa Timur dalam angka 2020," East Java Province, 2015.

[20] R. Baharta, F. Fathurohman, R. Purwasih, and N. Mukminah, "Analisis pengembangan kawasan peternakan ayam petelur (studi kasus di Kabupaten Subang)," Bulletin of Applied Animal Research, vol. 1, no. 1, pp. 26-30, 2019.

[21] Suparman, "Potensi pengembangan peternakan ayam broiler di Kecamatan Malunda Kabupaten Majene," Skripsi, Jurusan Ilmu Peternakan Fakultas Sains dan Teknologi, Universitas Islam Negeri Alauddin Makassar, 2017.

[22] A. Sari, Liman, and Muhtarudin, "Potensi daya dukung limbah tanaman palawija sebagai pakan ternak ruminansia di Kabupaten Pringsewu," Jurnal Ilmiah Peternakan Terpadu, vol. 4, no. 2, pp. 100-107, 2016.

[23] J. H. P. Sidadolog and T. Yuwanto, "Pengaruh konsentrasi protein-energi pakan terhadap pertambahan berat badan, efisiensi energi dan efisiensi protein pada masa pertumbuhan Ayam Merawang," Animal Production, vol. 11, no. 1, pp. 15-22, 2009.

[24] M. Z. Arifin and Riszqina, "Analisis potensi pengembangan ternak sapi potong melalui pendekatan lahan dan sumber daya manusia di Kecamatan Galis Kabupaten Pamekasan," Maduranch Jurnal Ilmu Ilmu Peternakan, vol. 1, no. 1, pp. 1-12, 2016.

[25] P. R. Matitaputty and B. Kuntoro, "Potensi dan strategi pengembangan kawasan peternakan ruminansia dan pemanfaatan limbah tanaman pangan di Kabupaten Maluku Tenggara Barat (MTB)," Jurnal Peternakan, vol. 7, no. 2, pp. 70-81, 2010. 
[26] A. D. Susanto, S. Soetriono, and A. Supriono, "Analisis perwilayahan dan strategi pengembangan peternakan kambing di Kabupaten Lumajang," SOROT, vol. 12, no. 2, pp. 107, 2017.

[27] B. Agustono, M. Lamid, A. Ma'ruf, and M. T. E. Purnama, "Identifikasi limbah pertanian dan perkebunan sebagai bahan pakan inkonvensional di Banyuwangi," Jurnal Medik Veteriner, vol. 1, no. 1, pp. 12-22, 2018.

[28] A. P. Sinurat, "Penggunaan bahan pakan lokal dalam pembuatan ransum ayam buras," Wartazoa, vol. 9, no. 1, pp. 12-21, 1999.

[29] E. Kasapidou, E. Sossidou, and P. Mitlianga, "Fruit and vegetable co-products as functional feed ingredients in farm animal nutrition for improved product quality," Agriculture, vol. 5, no. 4, pp. 1020-1034, 2015.

[30] M. Tafsin, L. A. Sofyan, N. Ramli, K. G. Wiryawan, K. Zarkasie, and W. G. Piliang, "Polisakarida mengandung mannan dari bungkil inti sawit sebagai antimikroba Salmonella typhimurium pada ayam," Media Peternakan, vol. 30, no. 2, pp. 139-146, 2007.

[31] T. Pasaribu, "Efforts to improve the quality of palm kernel cake through fermentation technology and enzyme addition for poultry," Indonesian Bulletin of Animal and Veterinary Sciences, vol. 28, no. 3, pp. 119-128, 2018.

[32] S. Panikkai, R. Nurmalina, S. Mulatsih, and H. Purwati, "Analysis of national corn availability to become self-sufficiency throught dynamic model approachmen," Informatika Pertanian, vol. 26, no. 1, pp. 41-48, 2017.

[33] I. G. N. G. Bidura, “Bahan makanan ternak," Program Studi Peternakan, Fakultas Peternakan, Universitas Udayana, 2016.

[34] F. A. Auza and R. Badaruddin, "Peningkatan nilai nutrisi kulit ari biji kedelai yang difermentasi dengan menggunakan teknologi efektivitas mikroorganisme (EM-4) dan waktu inkubasi yang berbeda," Jurnal Scientific Pinisi, vol. 3, no. 2, pp. 128-134, 2017.

[35] I. Astuti, "Pengaruh substitusi bungkil kedelai dengan bungkil wijen lokal terhadap efisiensi protein dan performan ayam broiler," Jurnal Sains Peternakan, vol. 5, no. 1, pp. 23-30, 2007.

[36] E. Syahruddin, R. Herawaty, A. Ibrahim, "Effect of substitution of fermented kapok seed (Ceiba petandra) to soybean meal on production and egg quality from native laying hens," Journal of Agricultural Science and Technology A, vol. 5, no. 2015, pp. 833-838, 2015.

[37] W. Widodo, "Nutrisi dan pakan unggas kontekstual," Direktorat Jenderal Pendidikan Tinggi Depdiknas, Jakarta, 2002.

[38] A. P. Sinurat, Pemanfaatan lumpur sawit untuk bahan pakan unggas," Wartazoa, vol. 13, no. 2, pp. 39-47, 2003.

[39] F. F. Tatilu, F. N. Sompie, M. Imbar, and Y. H. S. Kowel, "Pengaruh penggantian dedak halus dengan kulit kopi terhadap persentase karkas dan lemak abdomen broiler," Jurnal Zootek, vol. 35, no. 2, pp. 267-274, 2015.

[40] C. Inara, "Kajian tepung bungkil biji karet (TBBK) Havea brasiliensis sebagai bahan baku pakan benih ikan mas Cyprinus carpio Linn," Tesis, Sekolah Pascasarjana, Institut Pertanian Bogor, 2011.

[41] R. Hidayat, A. Setiawan, and E. Nofyan, "Pemanfaatan limbah kulit pisang lilin (Musa paradisiaca) sebagai pakan alternatif ayam pedaging (Gallus galus domesticus)," Jurnal Ilmu Lingkungan, vol. 14, no. 1, pp. 11-17, 2016.

[42] P. Pratiwi, "Penggunaan bahan pakan lokal dalam pembuatan ransum ayam buras," Wartazoa, vol. 9, no. 1, pp. 12-21, 1999.

[43] M. Astawan, and A. E. Febrinda, "Potensi dedak dan bekatul beras sebagai ingredient pangan dan produk pangan fungsional," Jurnal Pangan, vol. 19, no. 1, pp. 14-21, 2010.

[44] H. Hartadi, "Tabel-tabel Dari komposisi bahan makanan ternak untuk Indonesia, data ilmu makanan untuk Indonesia," Fakultas Peternakan, Universitas Gadjah Mada, Yogyakarta, 1980. 
[45] H. K. Dei, "Soybean as a feed ingredient for livestock and poultry," In D. Krezhova (Ed.), Recent Trends for Enhancing the Diversity and Quality of Soybean Products. InTech. https://doi.org/10.5772/17601

[46] R. A. Surya, "Pengaruh penggunaan kulit kecambah kacang hijau dalam ransum terhadap produksi karkas kelinci keturunan Vlaams Reus jantan," Skripsi, Fakultas Pertanian Universitas Sebelas Maret Surakarta, 2010.

[47] X. Zhao, J. Chen, and F. Du, "Potential use of peanut by-products in food processing: a review," Journal of Food Science and Technology, vol. 49, no. 5, pp. 521-529, 2012.

[48] M. D. Lindemann, E. T. Kornegay, and R. J. Moore, "Digestibility and feeding value of peanut hulls for swine," Journal of Animal Science, vol. 62, no. 2, pp. 412-421, 1986.

[49] A. Batal, N. Dale, and M. Café, "Nutrient composition of peanut meal," Journal of Applied Poultry Research, vol. 14, no. 2, pp. 254-257, 2005.

[50] N. Nuraini, A. Djulardi, and M. E. Mahata, "Pakan non konvensional fermentasi untuk unggas," Lembaga Pengembangan Teknologi Informasi dan Komunikasi (LPTIK) Universitas Andalas, 2017.

[51] M. Mirzah, and H. Muis, "Peningkatan kualitas nutrisi limbah kulit ubi kayu melalui fermentasi menggunakan Bacillus amyloliquefaciens," Jurnal Peternakan Indonesia (Indonesian Journal of Animal Science), vol. 17, no. 2, pp. 131-142, 2015.

[52] K. Kiramang, "Potensi dan pemanfaatan onggok dalam ransum unggas," Jurnal Teknosains, vol. 5, no. 2, pp. 155-163, 2011.

[53] K. Yanto and D. Febrina, "Potensi lumpur sawit (SOLID) sebagai pakan ruminansia di Kabupaten Pelalawan Provinsi Riau," Jurnal Agripet, vol. 8, no. 2, pp. 35-41, 2008.

[54] B. Putri, S. Hudaidah, and W. I. Kesuma, Pemanfaatan bungkil inti sawit sebagai media pertumbuhan cacing sutra (Tubifex sp.)," e-Jurnal Rekayasa dan Teknologi Budidaya Perairan, vol. 6, no. 2, pp. 729-738, 2018.

[55] H. H. Stein, G. A. Casas, J. J. Abelilla, Y. Liu, and R. C. Sulabo, "Nutritional value of high fiber coproducts from the copra, palm kernel, and rice industries in diets fed to pigs," Journal of Animal Science and Biotechnology, vol. 6, no. 1, p. 56, 2015.

[56] S. Guntoro and I. M. R. Yasa, "Penggunaan limbah kakao terfermentasi untuk pakan ayam buras petelur," Jurnal Pengkajian dan Pengembangan Teknologi Pertanian, vol. 8, no. 2, pp. 261-268, 2005.

[57] U. Nuschati, "Potensi limbah kulit kopi sebagai pakan ayam," Lokakarya Nasional Inovasi Teknologi, 2004.

[58] X. Ma, J. Hu, Q. Shang, H. Liu, and X. Piao, "Chemical composition, energy content and amino acid digestibility in cottonseed meals fed to growing pigs," Journal of Applied Animal Research, vol. 47, no. 1, pp. 280-288, 2019.

[59] C. M. Ajila, S. K. Brar, M. Verma, R. D. Tyagi, S. Godbout, and J. R. Valéro, "Bio-processing of agro-byproducts to animal feed," Critical Reviews in Biotechnology, vol. 32, no. 4, pp. 382-400, 2012.

[60] M. Dorisandi, L. Saputro, S. H. Jatmiko, and Y. Fenita, "Pengaruh pemberian fermentasi tepung kulit pisang jantan dengan menggunakan Neurospora crassa terhadap deposisi lemak ayam broiler," Jurnal Sain Peternakan Indonesia, vol. 12, no. 3, pp. 325-334, 2017.

[61] W. Alwi, L. Agustina, and M. Z. Mide, "Performa ayam arab dengan pemberian energi-protein pada level berbeda," Jurnal Sains dan Teknologi Peternakan, vol. 1, no. 1, pp. 7-12, 2019. 